\title{
A new subgenus Litochrus (Remitarsis): Notes on the Phalacridae (Coleoptera, Cucujoidea) from Indonesian Papua and the Australia
}

\author{
Новый подрод Litochrus (Remitarsis): заметки о Phalacridae \\ (Coleoptera, Cucujoidea) Западной Новой Гвинеи и Австрахии
}

\author{
G.Yu. Lyubarsky \\ Г.Ю. Аюбарский
}

Zoological Museum, Moscow State University, Bolshaya Nikitskaya Str. 2, Moscow 125009, Russia. Зоологический музей МГУ, ул. Большая Никитская 2, Москва 125009, Россия.

KEY WORDS. Phalacriidae, Litochrus, Remitarsis, new subgenus, new species, New Guinea, Australia, new records.

КЛЮЧЕВЫЕ СЛОВА.Phalacriidae, Litochrus, Remitarsis, новый подрод, новый вид, Новая Гвинея, Австралия, новые находки.

ABSTRACT. New subgenus of Litochrus Erichson, 1845 from New Guinea is described. Subgenus Litochrus (Remitarsis) subgen.n. is distinguished based on modified tarsomere 1 of posterior leg, its edges fairly flat, dilated, thinning to the side, strongly narrowed to the base, in the form similar to a paddle. This subgenus is described for the new species Litochrus (Remitarsis) eurypus sp.n. The new species is only known from $\mathrm{W}$ New Guinea where the species inhabits mountain ranges: Doberai Peninsula, Arfak mts. The data are analyzed on the findings of further six species in W New Guinea and Australia. Male genitalia are described for three species for the first time.

РЕЗЮМЕ. Описан новый подрод рода Litochrus Erichson, 1845 с Новой Гвинеи. Подрод Litochrus (Remitarsis) subgen.n. отличается изменённым 1 члеником задних лапок, который расширен, уплощен, сужен к основанию и утончён по краям, по форме напоминает весло. Новый подрод основан на описываемом новом виде Litochrus (Remitarsis) eurypus sp.n. Новый вид известен только с Западной Новой Гвинеи, где обитает в горной области: п-ов Добераи, горы Арфак. Приводятся данные о находках еще шести видов из Западной Новой Гвинеи и Австралии. Для трёх видов впервые описаны гениталии самцов.

\section{Introduction}

The phalacrid fauna of New Guinea comprises 26 species belonging to 4 genera: Augasmus Motschulsky, 1858 with three species, Austroporus Gimmel, 2013 with seven species, Litochrus Erichson, 1845 with 14 species, and Olibrus Erichson, 1845 with two species. Gimmel [2013] mentions two more genera without indication of the species: Phaenocephalus Wollaston, 1873, and Litochropus Casey, 1980.

General description of the family of Phalacridae can be found in Steiner [1984], Lawrence et al. [2010], and Gimmel [2013], its phylogenetic position in Robertson et al. [2015]. Phalacridae belong to the Laemophloeid group. Thomas [1984] suggested that Laemophloeidae, Propalticidae, Phalacridae and Passandridae form a natural lineage based on a number of morphological features including unequal protibial spurs, structural similarities of male genitalia, and the presence of pronotal lines and elytral cells. Recent studies have confirmed this view. According to the research by Robertson et al. [2015] and McElrath et al. [2015], there is a valid clade comprising Phalacridae and Laemophloeidae (incl. Propalticidae).

The Phalacridae of the Australian realm have been studying by two specialists. Firstly, many of them were described by Thomas Blackburn (1844-1912) [Blackburn, 1891]. Secondly, Arthur Mills Lea (1868-1932) in his monumental work on the Phalacridae of New Guinea [Lea, 1932] are described numerous species of the genera Phalacrus Paykull, 1800, Phalacrinus Blackburn, 1891, and Austroporus Gimmel, 2013. His described material and collection is deposited at the South Australian Museum in Adelaide (SAMA) [Setliff, 2007]. Unfortunately, in his work Lea did not use the characters of male genitalia, the descriptions being based on color patterns and shape of antennae and hind tibia.

Refinements on the Guinean fauna have been presented in several papers [Thompson, Marshall, 1980; Lyubarsky, 1994, 1996]. New findings of Litochrus [Lyubarsky, 2003] for New Guinea have been noted: Litochrus flavonotatus Lea, 1932; L. pallidipes Lea, 1932.

The phalacrid fauna of Australia has also been dealt with in several papers. Thus, Basset [1991] noted the presence of Litochrus in Australia, collected as part of larger collections of arthropods. Lea [1902] in his list of Tasmanian phalacrids points out Litochrus brunneus (Erichson, 1842), Olibrus victoriensis Champion, 1925, and Phalacus corruscus (Panzer, 1797). Phalacridae have been listed in the reports on pollinators: coleopter- 
an families for which anthophilous adults have been reported from Australia include, for example, such families as Meloidae, Mordellidae, Nitidulidae, Oedemeridae, and Phalacridae [Armstrong, 1979].

\section{Material and methods}

The study area was the Province of West Papua, Indonesia. The material was collected on the Arfak mountains known for their endemism and representing a relatively small and isolated mountain range at the Eastern coast of the Doberai Peninsula (also known as The Bird's Head or Vogelkop). The term "Arfak" came the language of the coastal Biak people, meaning "inferior". Arfak Mountains are a 2900-meter-high mountain range. The mountains begin almost at the coast, rising up very sharply, in many places almost vertically.

Equatorial latitudes are characterized by their own system of zones: tropical rainforest - mountain tropical forest - misty forest. So far, phalacrids have been collected at altitudes of 1800-2600 m, in misty forests of the middle mountain zone [McAlpine et al., 1983; Merlin, Juvik, 1995].

In September 2015 I received several phalacrid beetle specimens personally collected by the well-known coleopterist Dmitry Telnov (Riga, Latvia) on the Arfak Mointains in New Guinea. The beetles were collected on the light of a mercury vapor lamp. Additionally, considerable material from Australia was investigated.

New Guinea has a complex and recent history of geological changes. These processes may have caused faunal dissimilarity or promote endemism in different parts of apparently homogeneous lowland rainforests [Polhemus, Polhemus, 1998; Turner et al., 2001]. In Arfak Mointains there are many endemic species, including among vertebrates [Heads, 2002a,b]. Arfac Mointains accreted to northern New Guinea during the Miocene [Bain, 1973; Dow, 1977; Polhemus, Polhemus, 1998].

E. C. Zimmerman, a renowned specialist on weevils, wrote, "New Guinea reveals its geologic youth with an island biota in an exuberant state of explosive speciation." [Zimmerman, 1994]. On the other hand, New Guinea presents a zoogeographical puzzle. The fauna of New Guinea is composed of two components. The first probably entered Australasia from the north and in fairly recent times, sometime after the northern edge of the Australian Plate joined the southern margin of the Asian Plate. The second is the ancient Gondwanaland component. The impact of Australian biota on New Guinea has been of a limited nature, largely confined to limited areas of "Australian vegetation" in parts of SE New Guinea [Walker, 1972; Gressitt, 1982; Marshall, Beehler, 2012]. Although species endemism in New Guinea is high, generic endemism appears low in many groups [Gressitt, 1982]. To decipher this puzzle one needs to collect significant materials for different groups from New Guinea.

The investigated material is stored in two collections: CDT — collection Dmitry Telnov, Riga, Latvia; ZMUM Zoological Museum of Moscow State University.

\section{Taxonomical part}

Family Phalacridae Leach, 1815

Litochrus Erichson, 1845

Litochrus (Remitarsis) Lyubarsky subgen.n.

Type species Remitarsis eurypus sp.n.

DIAGNOSIS. Tarsomere 2 of anterior leg, tarsomere 2 of middle leg, and tarsomere 1 of posterior leg strongly dilated, in the form of a paddle (Figs 2-3). Tarsomere 1 of posterior leg fairly flat, thinning to the side edges, pubescent, strongly narrowed to the base. According to the diagnosis of this genus, there is a short subapical protibial ctenidium, which extends much less than half the distance of the tibia, metatarsomere I is longer than metatarsomere II, the metaventral process protrudes well anteriad the mesocoxae, the metaventral lines are not separate from the mesocoxal cavities.

ETYMOLOGY. As the new subgenus with tarsus is similar to a paddle, his name is a combination of the Latin words, remus and tarsus.

\section{Litochrus (Remitarsis) eurypus Lyubarsky sp.n.} Figs 1-5.

MATERIAL. Holotype, $0^{7}$ - Indonesia, W New Guinea, Doberai Peninsula, Arfak mts., Syoubri vill., $1^{\circ} 06^{\prime} 40^{\prime \prime} \mathrm{S}, 133^{\circ} 54^{\prime} 36^{\prime \prime}$, $1510 \mathrm{~m}, 12-13.09 .2015$, edge of secondary lower montane rainforest, MV light, leg. D. Telnov (ZMUM).

DESCRIPTION. Body color black and yellow: head, middle of pronotum, and disk of elytra around scutellum black, sides of pronotum, sides and apex of elytra bright yellow. On the elytra the black spot forms a triangular pattern around the scutellum, the sides of this triangle slightly wavy

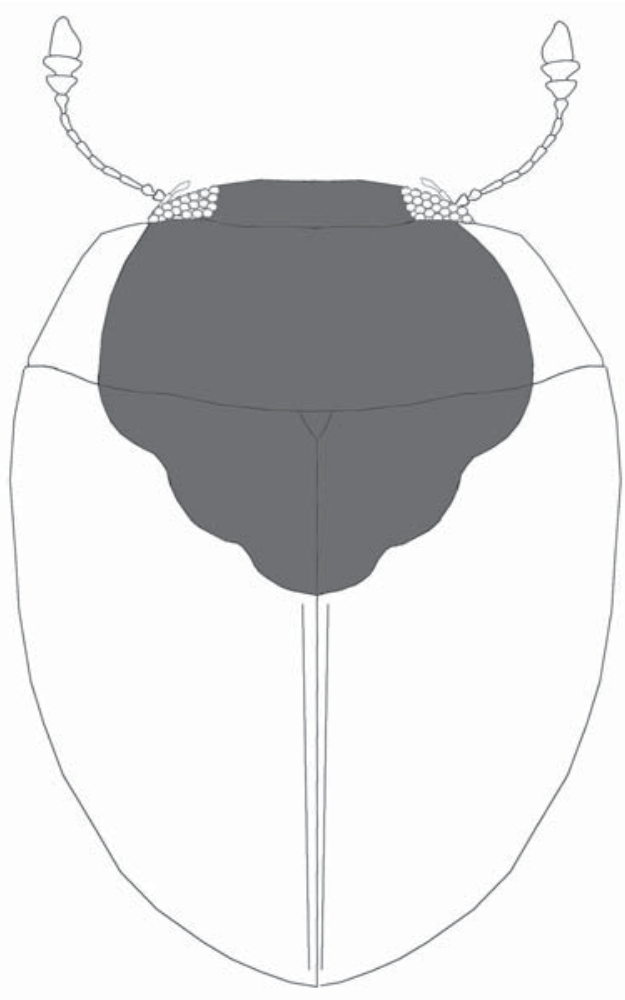

Fig. 1. Litochrus (Remitarsis) eurypus, subgen.n., sp.n., general view, dorsally.

Рис. 1. Litochrus (Remitarsis) eurypus, subgen.n., sp.n., общий вид, дорзально. 

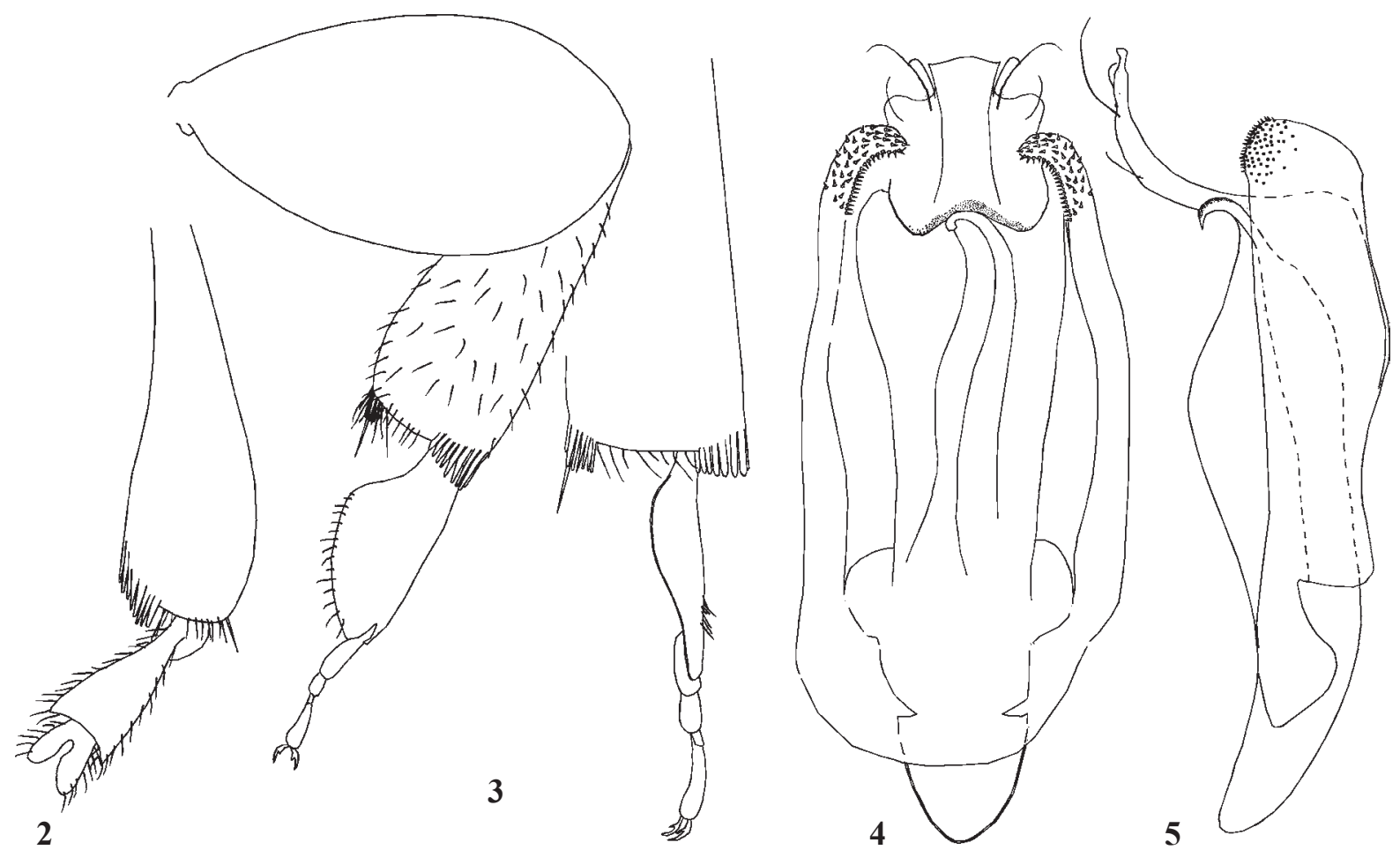

Figs 2-5. Litochrus (Remitarsis) eurypus, subgen.n., sp.n.: 2 - anterior tibia and tarsus; 3 - posterior tibia and tarsus (ventrally and laterally); 4 - aedeagus, ventrally; 5 - aedeagus, laterally.

Рис. 2-5. Litochrus (Remitarsis) eurypus, subgen.n., sp.n.: 2 - передняя голень и передняя лапка; 3 - задняя голень и задняя лапка, снизу и сбоку; 4 - гениталии самца, вентрально; 5 - гениталии самца, латерально.

(Fig. 1). Inferior surface dark-yellow to brown, antennae and palps yellow, legs dark-yellow.

Head. Eyes medium sized; facets convex. Antennae with 3 -segmented club, $3^{\text {rd }}$ antennomere longer than any other segment of flagellum, antennomeres 4-7 elongated, club symmetrical, antennomeres 9-11 flattened and dilated. Antennae not extending beyond the posterior edge of pronotum.

Thorax. Pronotum with moderately developed scutellar lobe. Forelegs thick, femora and tibia dilated, protibia with short ctenidium on outward surface, with group of ten or more spines at outer apical angle (Fig. 2). Tibial spur formula 2-2-2, tarsal formula 5-5-5. Longer spur of anterior tibia shorter than the width of the tibia at the top. Metaventral process marginated, extending to anterior level of mesocoxae, protruding and arcuately lobed anteriorly. Middle legs thick, femora and tibia dilated, longer spur of the tibia shorter than the width of the tibia at the top. Metathorax almost entirely punctured, only small areas around the posterior coxae not punctured. Puncturation of metathorax weak, sparse, distance between punctures about 2-3 diameters of puncture. Hind legs thick, femora and tibia dilated. Metatibia with short ctenidium. Longer spur of posterior tibia shorter than the width of the tibia at the top. Length of pronotum $0.5 \mathrm{~mm}$. Length of pronotum equal to 0.2 of its width.

Scutellum small, triangular, equilateral.

Elytron with one sutural stria; disc with rudimentary rows of punctures; without transverse strigae. Sutural stria on elytron extending to $2 / 3$ length of elytron. Distance between punctures on elytra about 8 diameters of puncture. Surface of elytra $a t$ intervals between rows of punctures very weakly and disorderly punctured. Surface of elytra shagreened. Length of elytra $2.4 \mathrm{~mm}$, elytra 4.8 times longer than pronotum.

Ventrites punctured and covered with pubescence.
Length of body $3.2 \mathrm{~mm}$. Maximal width of body $2.3 \mathrm{~mm}$. Genitalia of male as in Figs 4-5.

DISTRIBUTION. New Guinea.

ETYMOLOGY. The species is named because of the shape of the leg which is like a paddle and extended.

\section{Litochrus apiciflavus Lea, 1932}

Figs 6-8.

MATERIAL. Indonesia, W New Guinea, Doberai Peninsula, Arfak mts., Anggi Gigi Lake S env., Uper vill. \& surroundings, $1^{\circ} 18^{\prime} 10^{\prime \prime} \mathrm{S}, 133^{\circ} 54^{\prime} 03^{\prime \prime} \mathrm{E}, 1985 \mathrm{~m}, 8-9.09 .2015$, primary mid montane rainforest, white light, leg. D. Telnov, $1 \mathrm{O}^{\text {Th }}$ (ZMUM); W New Guinea, Doberai Peninsula, Arfak mts., Anggi Gigi Lake S env., Uper vill., $1^{\circ} 18^{\prime} 05^{\prime \prime} \mathrm{S}, 133^{\circ} 54^{\prime} 24^{\prime \prime} \mathrm{E}, 2200 \mathrm{~m}, 9-11.09 .2015$, edge of primary mid montane rainforest, white light, leg. D. Telnov, 4 구우 (CDT, ZMUM); W New Guinea, Doberai Peninsula, Arfak mts., Syoubri vill., $1^{\circ} 06^{\prime} 40^{\prime \prime} \mathrm{S}, 133^{\circ} 54^{\prime} 36^{\prime \prime} \mathrm{E}, 1510 \mathrm{~m}, 12$ 13.09.2015, edge of secondary lower montane rainforest, MV light, leg. D. Telnov, 4 우 (CDT).

This species is described from Australia. Lea indicates the following localities: Groote Eylandt; Roper River; Melville Island; Darwin; North Queensland; Port Douglas; Cairns; Endeavour River; Stradbroke Island; Bribie Island; Brisbane; New South Wales; Tweed River.

Lea [1932] depictured antenna and color pattern of elytra of this species [Lea, 1932: Figs 32, 79-81]. Color scheme of elytra in Fig. 8. Lea did not provide a drawing of male genitalia. The male genitalia are shown in Fig. 7.

DISTRIBUTION. Australia, New Guinea (new record).

\section{Litochrus basipennis Lea, 1932}

Figs 9-11.

MATERIAL. Indonesia, W New Guinea, Doberai Peninsula, Arfak mts., Anggi Gigi Lake S env., Uper vill., 1¹8'05'S, 
$133^{\circ} 54^{\prime} 24^{\prime \prime} \mathrm{E}, 2200 \mathrm{~m}, 9-11.09 .2015$, edge of primary mid montane rainforest, white light, leg. D. Telnov, $2 \sigma^{7} \sigma^{7} 2$ 우 (CDT, ZMUM); W New Guinea, Doberai Peninsula, Arfak mts., Syoubri vill., $1^{\circ} 06^{\prime} 40^{\prime \prime} \mathrm{S}, 133^{\circ} 54^{\prime} 36^{\prime \prime} \mathrm{E}, 1510 \mathrm{~m}, 12-13.09 .2015$, edge of secondary lower montane rainforest, whitelight, leg. D. Telnov, $1 \sigma^{7}$ 4 우 (CDT).

This species is described from Australia. Lea indicates the following localities: New South Wales (Dorrigo; Comboyne; Upper Williams River); Queensland (Buderim Mountain; Cairns).

Lea [1932] depictured antenna, hind leg and color pattern of elytra of this species [Lea, 1932: Figs 30-31, 73-76]. Color scheme of elytra in Fig. 8 [Lea, 1932] did not provide a drawing of male genitalia. The male genitalia are shown in Fig. 10 .

DISTRIBUTION. Australia, New Guinea (new record).

Litochrus bicolor (Lyubarsky, 1996)

MATERIAL. Indonesia, W New Guinea, Doberai Peninsula, Ayamaru vill. 8,3 km SE, $1^{\circ} 18^{\prime} 54^{\prime \prime} \mathrm{S}, 132^{\circ} 15^{\prime} 28^{\prime \prime} \mathrm{E}, \sim 360 \mathrm{~m}, 2-$ 3.09.2015, primary lowland rainforest on limestone, white light, leg. D. Telnov, 1 (CDT)

This species is described from Papua New Guinea. Type material: Sepik River; Hauptlager b. Malu.

DISTRIBUTION. New Guinea (new record to Indonesia).
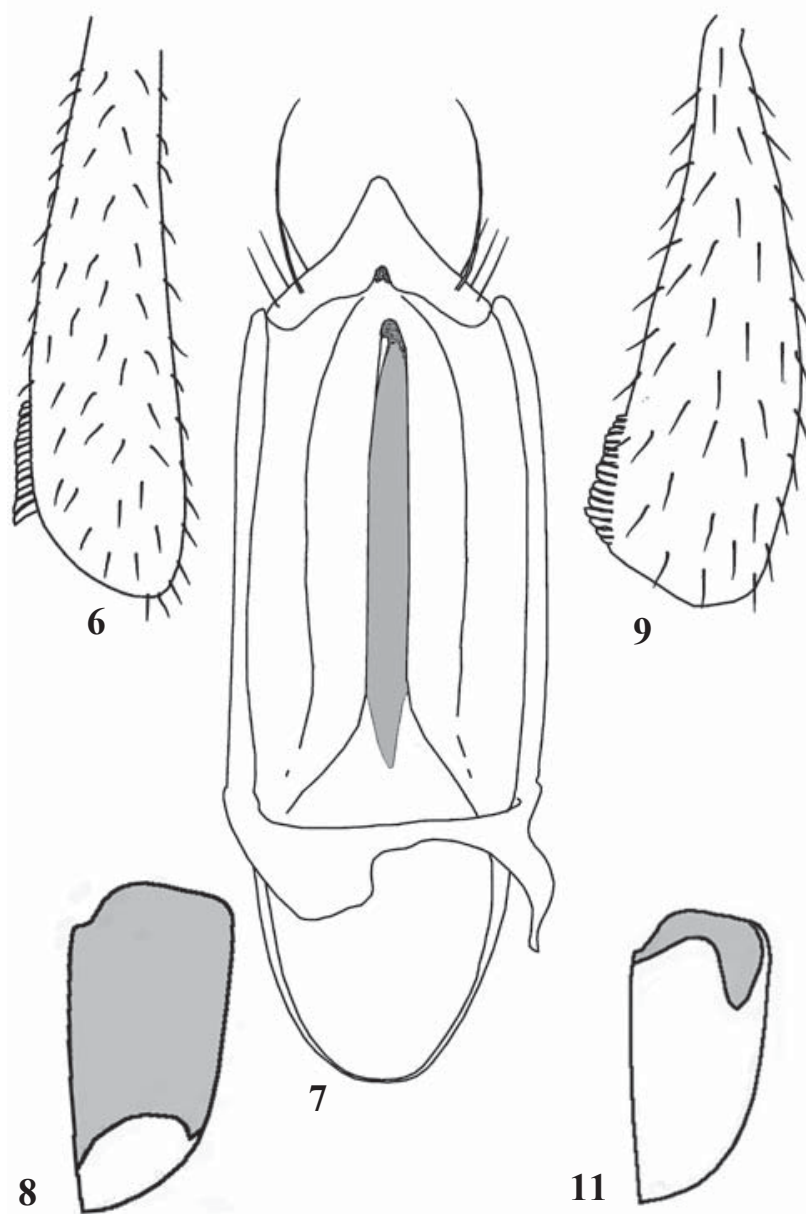

11
Litochrus caeruleotinctus Lea, 1932

Figs 12-13.

MATERIAL. W New Guinea, Doberai Peninsula, Arfak mts., Syoubri vill., $1^{\circ} 06^{\prime} 40^{\prime \prime} \mathrm{S}, 133^{\circ} 54^{\prime} 36^{\prime \prime} \mathrm{E}, 1510 \mathrm{~m}, 12-13.09 .2015$, edge of secondary lower montane rainforest, MV light, leg. D. Telnov, $1 \sigma^{7} 2$ 90 (CDT, ZMUM); Doberai Peninsula, Ayamaru vill., $\sim 8,3 \mathrm{~km}$ $\mathrm{SE}, 1^{\circ} 18^{\prime} 54^{\prime \prime} \mathrm{S}, 132^{\circ} 15^{\prime} 28^{\prime \prime} \mathrm{E}, \sim 360 \mathrm{~m}, 2-3.09 .2015$, primary lowland rainforest on limestone, white light, leg. D. Telnov, $1+$ (CDT).

This species is described from New Guinea. Lea indicates the following localities: Finsch Javen; Papua New Guinea: Mount Lamington. Lea noted that this species is also found in Australia: Dunk Island.

Lea [1932] depictured hind leg and antenna of this species [Lea, 1932: Figs 6-7]. Lea did not provide a drawing of male genitalia. The male genitalia are shown in Fig. 13.

DISTRIBUTION. Australia, New Guinea.

REMARKS. Key to the species of the genus Litochrus of black color from Australia and New Guinea. The species of two-colors, yellow and brown, with shading along the seam are not included in the key.

1. Body length of less than $1.6 \mathrm{~mm}$... L. amabilis Guilleb.

- Body length of more than $1.6 \mathrm{~mm}$..... L..................... 2

. Elytra with 2 sutural lines

- Elytra with 1 sutural line

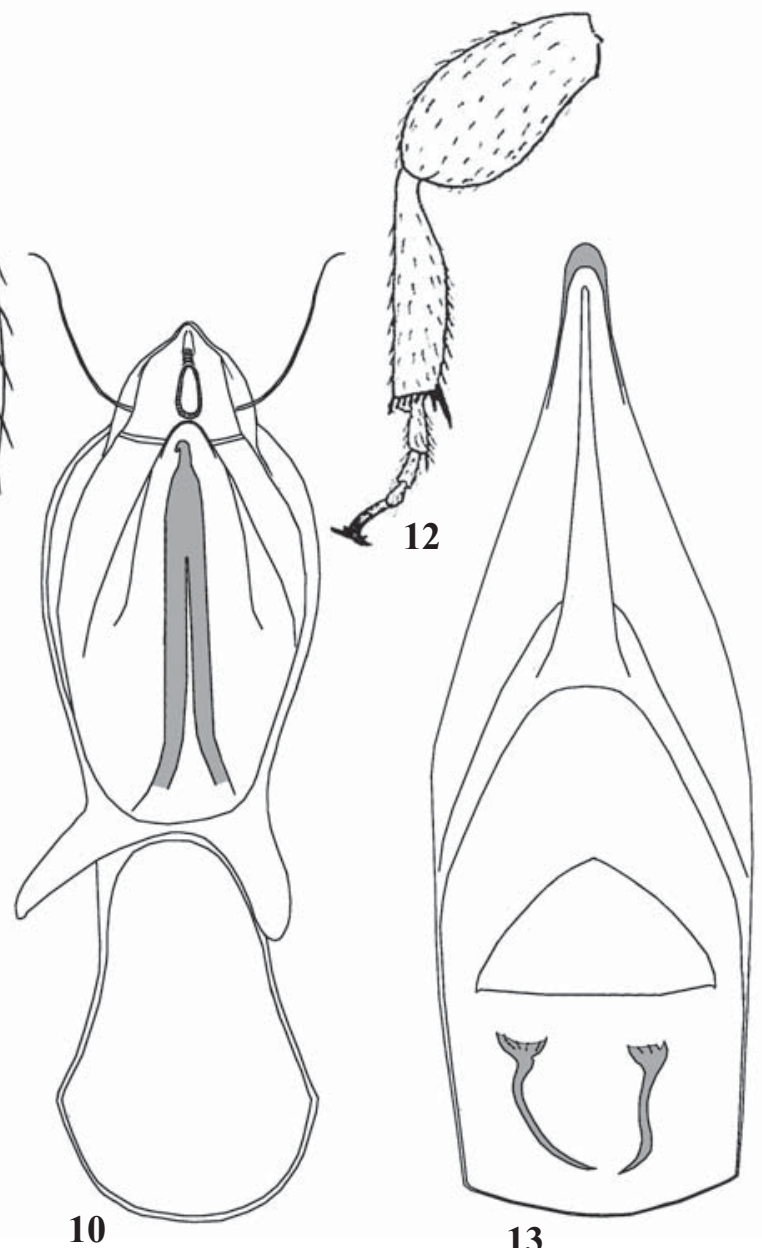

Figs 6-13. Litochrus spp.: 6-8-L. apiciflavus; 9-11-L. basipennis; 12-13- L. caeruleotinctus; 6, 9- posterior tibia; 7, 10, 13 aedeagus; 8, 11 - color scheme of elytra; 12 - posterior leg; 8, 11-12 - after Lea, 1932.

Рис. 6-13. Litochrus spp.: 6-8-L. apiciflavus; 9-11 - L. basipennis; 12-13-L. caeruleotinctus; 6, 9- задняя голень; 7, 10, 13 гениталии самца; 8, 11 - схема окраски надкрылий; 12 - задняя нога; 8, 11-12 - по Lea, 1932. 
3. $1^{\text {st }}$ tarsomere of hind tarsus in 2 times longer than $2^{\text {nd }}$ tarsomere .. 4

- $1^{\text {st }}$ tarsomere of hind tarsus in 1.5 times longer than $2^{\text {nd }}$ tarsomere

4. Body length of less than $2.2 \mathrm{~mm}$ L. nigritulus (Lyubarsky)

— Body length of more than $2.3 \mathrm{~mm}$....... L. pallidipes Lea

5. Body length of less than $2 \mathrm{~mm}$. Spur of posterior tibia longer than the width of the tibia at the top. L. obscuripes Lea

- Body length of more than $2 \mathrm{~mm}$. Spur of posterior tibia shorter than the width of the tibia at the top. L. caeruleotinctus Lea

\section{Litochrus maculatus Blackburn, 1891}

MATERIAL. Indonesia, W New Guinea, Doberai Peninsula, Arfak mts., Anggi Gigi Lake S env., Uper vill., $1^{\circ} 18^{\prime} 05^{\prime \prime} \mathrm{S}$, $133^{\circ} 54^{\prime} 24^{\prime \prime} \mathrm{E}, 2200 \mathrm{~m}, 9-11.09 .2015$, edge of primary mid montane rainforest, white light, leg. D. Telnov, 1 (CDT); W New Guinea, Doberai Peninsula, Arfak mts., Syoubri vill., $1^{\circ} 06^{\prime} 40^{\prime \prime} \mathrm{S}$, $133^{\circ} 54^{\prime} 36^{\prime \prime} \mathrm{E}, 1510 \mathrm{~m}, 12-13.09 .2015$, edge of secondary lower montane rainforest, whitelight, leg. D. Telnov, $1 \sigma^{7}$ (ZMUM); W New Guinea, Doberai Peninsula, Arfak mts., Anggi Gigi Lake S env., Uper vill. \& surroundings, $1^{\circ} 18^{\prime} 10^{\prime \prime} \mathrm{S}, 133^{\circ} 54^{\prime} 03^{\prime \prime} \mathrm{E}, 1985 \mathrm{~m}$, $8-9.09 .2015$, primary mid montane rainforest, white light, leg. D. Telnov. 1 क (CDT).

Lea [1932] depictured the color pattern of elytra for this species [Lea, 1932: Figs 105-111].

This species is described from Australia. Lea indicates the following localities in Blackborn's collection: Queensland: Cairns; New South Wales: Armidale; Forest Reefs; Tamworth; Wentworth Falls; Victoria: Alps; Benalla; Dividing Range; Tasmania: Devonport; Hobart; Huon River; Launceston; South Australia: Lucindale; Mont Lofty; Port Lincoln; Tumby; est Australia: Albany; Mount Barker; Swan River.

DISTRIBUTION. Australia, Tasmania; New Guinea (new record).

\section{Litochrus maritimus Blackburn, 1903}

MATERIAL. Australia. N of Sydney, Pearl Beach at Broken Bay, 7.03.1997, leg. D. Scherbakov, 1 spec. ZMUM.

This species is described from Australia. Lea indicates the following localities in Blackborn's collection: Queensland: Bribie Island; Cairns; New South Wales: Sydney; Victoria: Glenelg River; South Australia: Kangaroo Island; Mount Gambier; Mount Lofty.

DISTRIBUTION. Australia.

\section{Austroporus sp. indet}

MATERIAL. Indonesia, W New Guinea, Doberai Peninsula, Arfak mts., Anggi Gigi Lake S env., Uper vill., $1^{\circ} 18^{\prime} 05^{\prime \prime} \mathrm{S}$, $133^{\circ} 54^{\prime} 24^{\prime \prime} \mathrm{E}, 2200 \mathrm{~m}, 9-11.09 .2015$, edge of primary mid montane rainforest, white light, leg. D. Telnov, 1 ㅇ (CDT); W New Guinea, Doberai Peninsula, Arfak mts., Syoubri vill., $1^{\circ} 06^{\prime} 40^{\prime \prime} \mathrm{S}$, $133^{\circ} 54^{\prime} 36^{\prime \prime} \mathrm{E}, 1510 \mathrm{~m}, 12-13.09 .2015$, edge of secondary lower montane rainforest, whitelight, leg. D. Telnov, 1 \& (ZMUM); the same data, MV light, leg. D. Telnov, 1 (CDT).

REMARKS. Possibly, this is a new species, at least it is not among the species described by Lea and Blackburn. Body black, shiny, elytra with big red spot common to both. The red spot can be of different shapes, sometimes rounded, not reaching the sides of the elytron, sometimes clarified area spreading forward, so only the scutellar area and the very top of the elytron remain dark. Elytra with 1 sutural line.

On the grounds of external morphology, this is a new species, not described by Lea, but all the studied specimens are females, so there is no opportunity to see the male genitalia and describe this species.

\section{Olibrus sp. indet.}

Fig. 14.

MATERIAL. Indonesia, W New Guinea, Doberai Peninsula, Arfak mts., Anggi Gigi Lake S env., Uper vill., $1^{\circ} 18^{\prime} 05^{\prime \prime} \mathrm{S}$, $133^{\circ} 54^{\prime} 24^{\prime \prime} \mathrm{E}, 2200 \mathrm{~m}, 9-11.09 .2015$, edge of primary mid montane rainforest, white light, leg. D. Telnov, $1 \mathrm{O}^{\text {Th }}$ (CDT).

REMARKS. Body dark-brown, pronotum darker. Pronotum punctured weakly and rarely. Posterior margin of pronotum bordered along the entire length. Elytral surface with one sutural stria. Elytral surface covered by row of punctures. The distance between the rows is 5 diameters of puncture. $1^{\text {st }}$ tarsomere of hind tarsus smaller than $2^{\text {nd }}$ tarsomere.

Unfortunately, there is only one specimen of this species. Only three species of the genus Olibrus (O.albomaculatus Motschulsky, 1858, O.igneus Fauvel, 1903, O.rufescens Motschulsky, 1858) have been recorded for the Australian region, this species differs from all of them, including in the structure of genitals. However, from the Oriental realm 17 species of this genus have been described. This specimen from New Guinea is probably a new species.

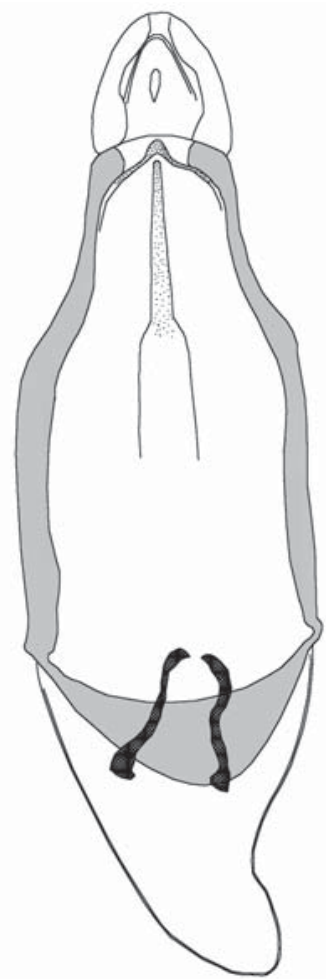

Fig. 14. Olibrus sp., aedeagus.

Рис. 14. Olibrus sp., гениталии самца.

ACKNOWLEDGMENTS. We are grateful to Dr. Dmitry Telnov (Riga, Latvia) for providing the material for study. This study was supported by Research project of Zoological Museum of MSU (AAAA-A16-116021660077-3).

\section{References}

Armstrong J.A. 1979. Biotic pollination mechanisms in the Australian flora - a review // N. Z. J. Botany. Vol.17. P.467-508.

Bain J.H.C. 1973. A summary of the main structural elements of Papua New Guinea // Coleman P.J. (ed.). The Western Pacific: Nedlands. Western Australia: University of Western Australia Press. P.147-161. 
Basset Y. 1991. The Taxonomic Composition of the Arthropod Fauna Associated with an Australian Rainforest Tree // Austral. J. Zool. Vol.39. P.171-190.

Blackburn T. 1891. Further notes on Australian Coleoptera, with descriptions of new species, ix // Trans. Roy. Soc. South Australia. Vol.14. P.65-153.

Dow D.B. 1977. A geological synthesis of Papua New Guinea Volume 201 of Bulletin (Australia. Bureau of Mineral Resourc es, Geology and Geophysics). Australian Government Publishing Service. $41 \mathrm{p}$.

Gimmel M.L. 2013. Genus-level revision of the family Phalacridae (Coleoptera: Cucujoidea) // Zootaxa. Vol.3605. No.1. P.1147.

Gressitt J.L. 1982. Ecology and biogeography of New Guinea Coleoptera (Beetles) // Monographiae Biologicae. The Hague: Dr. W. Junk Publ. Vol.42. P.709-734

Heads M. 2002a. Birds of paradise, vicariance biogeography and terrane tectonics in New Guinea // J. Biogeogr. Vol.29. P.261283.

Heads M. 2002b. Regional patterns of biodiversity in New Guinea animals // J. Biogeogr. Vol.29. P.285-294

Lawrence J.F., Gimmel M.L., Steiner W.E. 2010. Phalacridae // Leschen R.A.B., Beutel R.G., Lawrence J.F. (eds.). Morphology and Systematics (Elateroidea, Bostrichiformia, Cucujiformia partim). Vol.4. Pt.39. Handbuch der Zoologie. Arthropoda. Insecta. Coleoptera, Beetles. Berlin, New York: Walter de Gruyter. 799 p.

Lea A.M. 1902. List of the described Coleoptera of Tasmania // Report of the 9th meeting of AAAS, Proceedings of Section D. P.432-457.

Lea A.M. 1932. The Phalacridae (Coleoptera) of Australia and New Guinea // Rec. S. Austral. Mus. Vol.4. P.433-481.

Lyubarsky G.Y. 1994. New and little-known Phalacridae (Coleoptera Clavicornia) from the Oriental region // Russian Entomol. J. Vol.3. Nos1-2. P.49-59.

Lyubarsky G.Yu. 1996. Species of the genus Augasmus (Coleoptera, Phalacridae) from New Guinea in the collection of Zoological Museum (Berlin) // Russian Entomol. J. Vol.5. Nos1-4. P.3948.

Lyubarsky G.Yu. 2003. Phalacridae (Coleoptera) from Nepal and other districts of Oriental Realm // Russian Entomol. J. Vol.12. No.1. P.59-68.

McAlpine J.R., Keig G., Falls R. 1983. Climate of Papua New Guinea. Canberra: CSIRO and Australian National University Press. 209 p.
McElrath T.C., Robertson J.A., Thomas M.C., Osborne J., Miller K.B., McHugh J.V., Whiting M.F. 2015. A molecular phylogenetic study of Cucujidae s.1. (Coleoptera: Cucujoidea) // Syst. Entomol. Vol.40. No.4. P.1-14 DOI: 10.1111/syen.12133.

Marshall A., Beehler B. (eds.). 2012. The Ecology of Papua: Part One. Singapore: Tuttle Publishing. 782 p.

Merlin M.D., Juvik J.O. 1995. Montane cloud forest in the tropical Pacific: some aspects of their floristics, biogeography, ecology, and conservation // Hamilton L.S., Juvik J.O., Scatena F.N. (eds.). Tropical Montane cloud Forests: Proceedings of an International Symposium. New York: Springer-Verlag. P.149-162.

Polhemus D.A., Polhemus J.T. 1998. Assembling New Guinea: 40 million years of island arc accretion as indicated by the distributions of aquatic Heteroptera (Insecta) // Hall R., Holloway J.D. (eds.). Biogeography and geological evolution of SE Asia. Leiden: Backhuys. P.327-340.

Robertson J.A., Slipinski A., Moulton M., Shockley F.W., Giorgi A., Lord N.P., McKenna D.D., Tomaszewska W., Forrester J., Miller K.B., Whiting M.F., McHugh J.V. 2015. Phylogeny and classification of Cucujoidea and the recognition of a new superfamily Coccinelloidea (Coleoptera: Cucujiformia) // Syst. Entomol. Vol.40. No.4. P.745-778.

Setliff G.P. 2007. Annotated checklist of weevils from the Papuan region (Coleoptera, Curculionoidea) // Zootaxa. Vol.1536. P.1296.

Steiner W.E. 1984. A review of the biology of phalacrid beetles // Wheeler Q., Blackwell M. (eds.). Fungus-insect relationships. NewYork: Columbia University Press. P.424-445.

Thomas M.C. 1984. A new Neotropical genus and species of rostrate Laemophloeinae (Coleoptera: Cucujidae) with discussion of the systematic position of the subfamily // The Coleopterists Bulletin. Vol.38. P.67-83.

Thompson R.T., Marshall J.E. 1980. A taxonomic study of Phalacrus uniformis (Coleoptera: Phalacridae), an Australian beetle now established in New Zealand // New Zealand J. Zool. Vol.7. P.407-416.

Turner H., Hovenkamp P., van Welzen P.C. 2001. Biogeography of South East Asia and the West Pacific // J. Biogeogr. Vol.23. P. 217-230.

Walker D. 1972. Bridge and barrier: the natural and cultural history of Torres Strait // Res. School Pacific Studies, Publ. BG/3. Australian National Univ. 437 p.

Zimmerman E.C. 1994. Australian Weevils (Coleoptera: Curculionoidea) I: Anthribidae to Attelabidae: The Primitive Weevils. Melbourne: CSIRO Publishing. 741 p. 